\title{
Fallout Tephras of the 2006-2007 Eruptions of the Bulusan Volcano, Southern Luzon, Philippines
}

\author{
Perla J. DELOS REYES*, Ma. Antonia V. BORNAS*, Ma. Carmencita B. ARPA*, \\ Eduardo LAGUERTA*, Mabelline T. CAHULOGAN*, Raymond Patrick R. MAXIMO*, \\ Ma. Hannah T. MIRABUENO*+, Jeffrey S. PEREZ* , Bella S. TUBIANOSA* \\ and Renato U. SOLIDUM, Jr.*
}

[Recived 28 November, 2011; Accepted 27 July, 2014]

\begin{abstract}
The Bulusan volcano is one of the active volcanoes in the Philippines, and is located in southern Luzon. In 2006 and 2007, 19 and 7 distinct phreatic eruptions of the volcano occurred, respectively. Each discrete event produced tephra that was dispersed by prevailing winds mainly to the west or southwest of the summit vent, blanketing portions of the western Sorsogon Peninsula. Some events were recorded as explosion-type earthquakes. Whenever possible, fallout tephra deposits were mapped and sampled to determine the volume and composition of material produced from each eruptive event. Based on the dispersal maps, the average volume was estimated to be $10^{5} \mathrm{~m}^{3}$. No juvenile magma were detected in ash and lithic samples by petrographic and X-ray fluorescence analysis. Therefore, all analyzed samples were considered products of phreatic eruptions.
\end{abstract}

Key words : Bulusan volcano, phreatic eruption, ash fall, juvenile magma, Philippines

\section{Introduction}

Bulusan volcano $\left(12^{\circ} 46.2^{\prime} \mathrm{N}, 124^{\circ} 03.0^{\prime} \mathrm{E}\right)$ is situated in the central part of the Sorsogon Peninsula, at the southern end of the Bicol Volcanic Arc (Fig. 1). It is located $70 \mathrm{~km}$ southeast of the better known Mayon volcano, and $250 \mathrm{~km}$ southeast of metro Manila. It has erupted at least 17 times since its first recorded eruption in 1852. The eruption styles have been classified into two types: (1) Strombolian (e.g., 1918-1919), and (2) phreatic or phreatomagmatic (e.g., 19181922, 1979-81, 1983, 1988, 1994-95, 2006-07, 2010-11). Saderra Maso (1911) described the eruptions of 1852, 1889, and 1894 as having a few small outbursts with the ejection of ash. This is typical of the activity exhibited during the more recent eruptions. Here we describe the eruptive events of 2006 and 2007, and characterize their fallout tephras. Relevant seismic and other related observation data derived from the "Volcano Bulletins" and various "internal reports" of investigations conducted by Philippine Institute of Volcanology and Seismology (PHIVOLCS) are also presented in this paper.

\footnotetext{
* Philippine Institute of Volcanology and Seismology (PHIVOLCS), Department of Science and Technology (DOST), C.P. Garcia Ave., UP Diliman, Quezon City, Philippines

+ Present Address: Christchurch City Council, Christchurch, New Zealand
} 

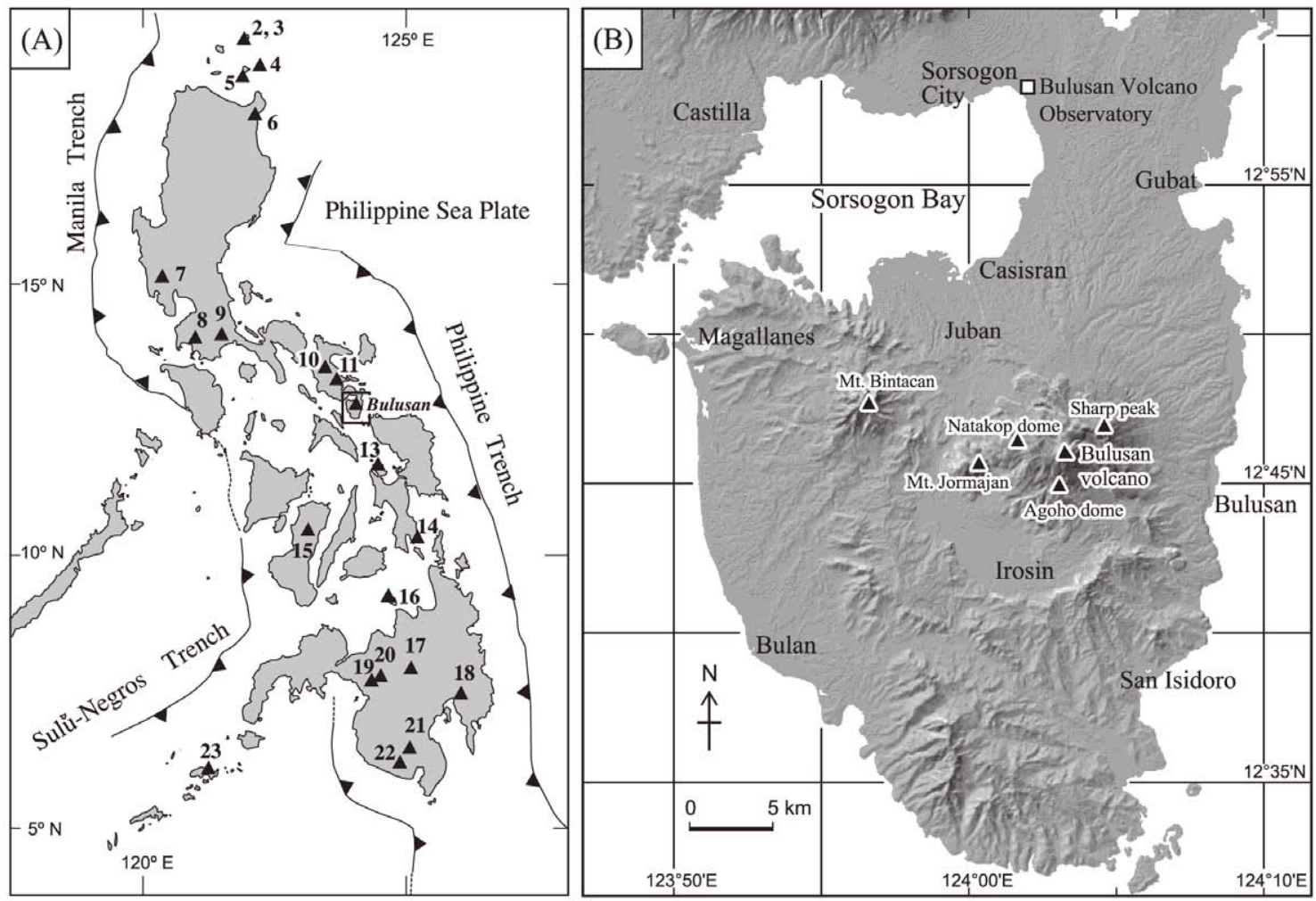

Fig. 1 Index maps. (A) Active volcanoes in the Philippines (PHIVOLCS, 2002 ${ }^{1)}$ ). Rectangle indicates area of (B). Numbers for active volcanoes were provided by PHIVOLCS ${ }^{1)}$. The Bulusan volcano is number "12". (B) Topographic map around Bulusan volcano. Names of municipalities are also shown. Base map was created from SRTM data using KASHMIR rendering software.

\section{Geological setting and history of the Bulusan volcano}

The Bulusan volcano is an andesitic stratovolcano and dome complex on the northeast rim of the 41-cal $\mathrm{kBP}$ Irosin caldera, and is one of the most active volcanoes in the Philippines (PHIVOLCS, 2002 ${ }^{1)}$ ). It stands $1559 \mathrm{~m}$ above sea level with a base area of approximately $400 \mathrm{~km}^{2}$. The volcano has rugged topography resulting from multiple lateral vent and dome growth, forming vertical cliffs, deep gullies, and gorges primarily composed of lava flow deposits, and is flanked by small, gently sloping pyroclastic and lahar aprons. Grass and bare ash, thick dense tropical forest, and coconut groves cover the upper, middle, and lower slopes, respectively. The $2006-2007$ eruptive events and the more recent November 2010 and February 2011 events (e.g., Okuno et al., 2011; Kinoshita and Laguerta, 2014) bring the number of historical Bulusan eruptions to 17. PHIVOLCS has instituted an alert level system (Table 1) to evaluate the activity of the volcano.

\section{Chronology of the eruptive events}

Dispersal maps of the ash falls of the 2006 and 2007 eruptions at Bulusan volcano are shown in Figs. 2 and 3. In this chapter, we describe the eruptions in chronological order, including seismic and other related observation data.

\section{1) The 2006 eruptive events and fallout tephra}

Nineteen distinct phreatic eruptive events occurred at Bulusan in 2006. Prior to the first event 
Table 1 Alert level signals for the Bulusan volcano.

\begin{tabular}{cll}
\hline $\begin{array}{l}\text { Alert } \\
\text { Level }\end{array}$ & \multicolumn{1}{c}{ Criteria } & \multicolumn{1}{c}{ Interpretation } \\
\hline 0 & Background, quiet & No eruption in foreseeable future \\
1 & Low level of seismic, fumarolic, and other unrest & $\begin{array}{l}\text { Magmatic, tectonic or hydrothermal disturbance; } \\
\text { no eruption imminent }\end{array}$ \\
2 & $\begin{array}{l}\text { Moderate level of seismic, other unrest with positive } \\
\text { evidence for involvement of magma }\end{array}$ & $\begin{array}{l}\text { Probable magma intrusion; could eventually lead } \\
\text { to an eruption }\end{array}$ \\
& $\begin{array}{l}\text { Relatively high and increasing unrest, including numer- } \\
\text { ous low frequency volcanic earthquakes, accelerating } \\
\text { ground deformation, increasing fumarolic activity. }\end{array}$ & $\begin{array}{l}\text { Increasing likelihood of an eruption, possibly ex- } \\
\text { plosive, probably within days to weeks. }\end{array}$ \\
4 & $\begin{array}{l}\text { Intense unrest, including harmonic tremor and / or many } \\
\text { "long-period" (i.e., low frequency) earthquakes and / or } \\
\text { dome growth and / or small explosions }\end{array}$ & $\begin{array}{l}\text { Magma close to or at the earth's surface. Hazard- } \\
\text { ous explosive eruption likely, possibly within hours } \\
\text { or days. }\end{array}$ \\
$\begin{array}{l}\text { Hazardous eruption in progress. Hazards in valleys and } \\
\text { downwind. }\end{array}$ & \\
\hline &
\end{tabular}

on March 21, its seismic network recorded 73 high-frequency volcanic earthquakes in the 24-h period between $0600 \mathrm{~h}$ Philippine Standard Time (PST) on March 18 and $0600 \mathrm{~h}$ PST on March 19 (Table 2). The seismic swarm marked in an increase in the average daily volcanic seismicity compared to the typical background rate of less than five events daily. As a precaution against the sudden hydrovolcanic eruptions for which Bulusan is known, PHIVOLCS on March 19 raised the volcano status from Alert Level Zero (no alert) to Alert Level 1 to reflect the elevated seismicity. The first of the phreatic explosions occurred at $2258 \mathrm{~h}$ PST on March 21, producing an ash column that rose $1.5 \mathrm{~km}$ above the summit. The Bulusan Seismic Network detected an explosiontype earthquake that lasted for $20 \mathrm{~min}$, and lightning flashes and rumbling sounds accompanied ash ejection. Three subsequent explosion-type earthquakes were also detected at $2330 \mathrm{~h}, 2332 \mathrm{~h}$, and $2337 \mathrm{~h}$ PST, but the corresponding eruptive events could not be observed due to the obscuring of the summit. One hour after these events, light ash fall (approximately $5 \mathrm{~mm}$ in thickness) was reported by residents on the northern, western, and southwestern flanks of the volcano, including the barangays (villages) of Cogon, Tinampo, Gulang-gulang, and Bolos in Irosin, and Puting Sapa and Bura-Buran in the Juban Municipalities
(Fig. 1B). After this series of events, the number of volcanic earthquakes decreased significantly until the succeeding eruptive events on April 29. Lower-magnitude phreatic eruptions in 2006 are listed and described in Table 2.

Another series of phreatic eruptions occurred in June 2006, after which a Quick Response Teams (QRT) was deployed by PHIVOLCS to map and sample all recently emplaced deposits (Arpa et al., 2006). The June events were relatively low magnitude, with ash plumes rising 1-2 $\mathrm{km}$ from the summit of the volcano. Minor pyroclastic flows may have been generated, but these were likely confined to the deep gullies near the summit area, within the 4-km-radius Permanent Danger Zone (PDZ). In general, however, the products of all of the March to June 2006 eruptions were largely characterized by fallout tephra. Dispersal maps for the discrete events are shown in Fig. 2. Rough calculations of the cumulative volume of tephra deposits from the March 21, April 29, May 25 and 31 , and June 7, 10, 13 and 18 events yielded values of approximately $1 \times 10^{6} \mathrm{~m}^{3}$. Bulusan lapsed into a period of quiescence for more than 5 weeks following the June events, as seismic, visual, and ground-deformation monitoring parameters were recorded at baseline levels. On July 29, 2006 PHIVOLCS lowered the volcano status to Alert Level 1. Then, without any seismic precursors, 

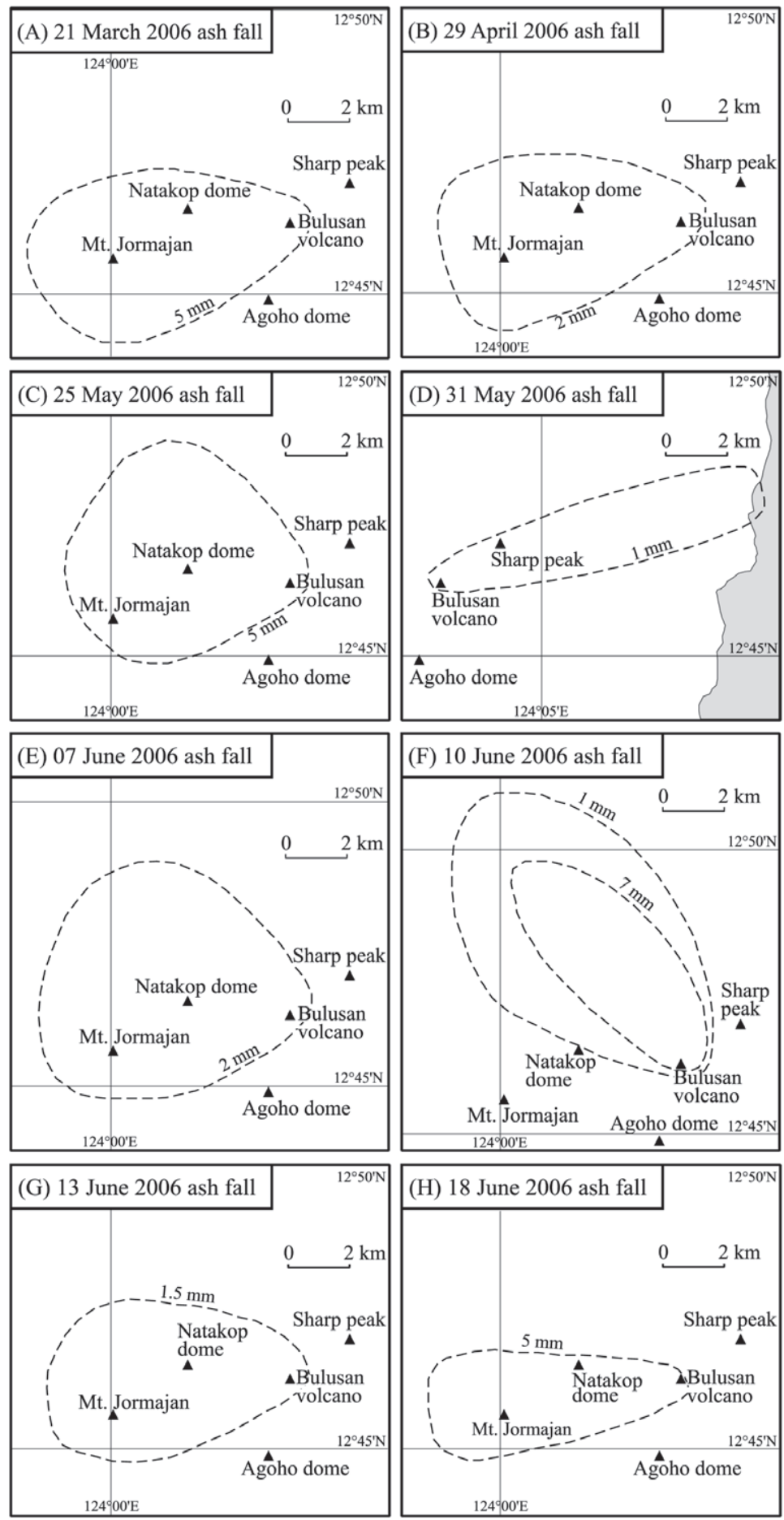

Fig. 2 Dispersal maps of ash fall from the phreatic eruptions at Bulusan volcano from March to June 2006 (modified from Arpa et al., 2006). (A) March 21, 2006, (B) April 29, 2006, (C) May 25, 2006, (D) May 31, 2006, (E) June 7, 2006, (F) June 10, 2006, (G) June 13, 2006, (H) June 18, 2006. 

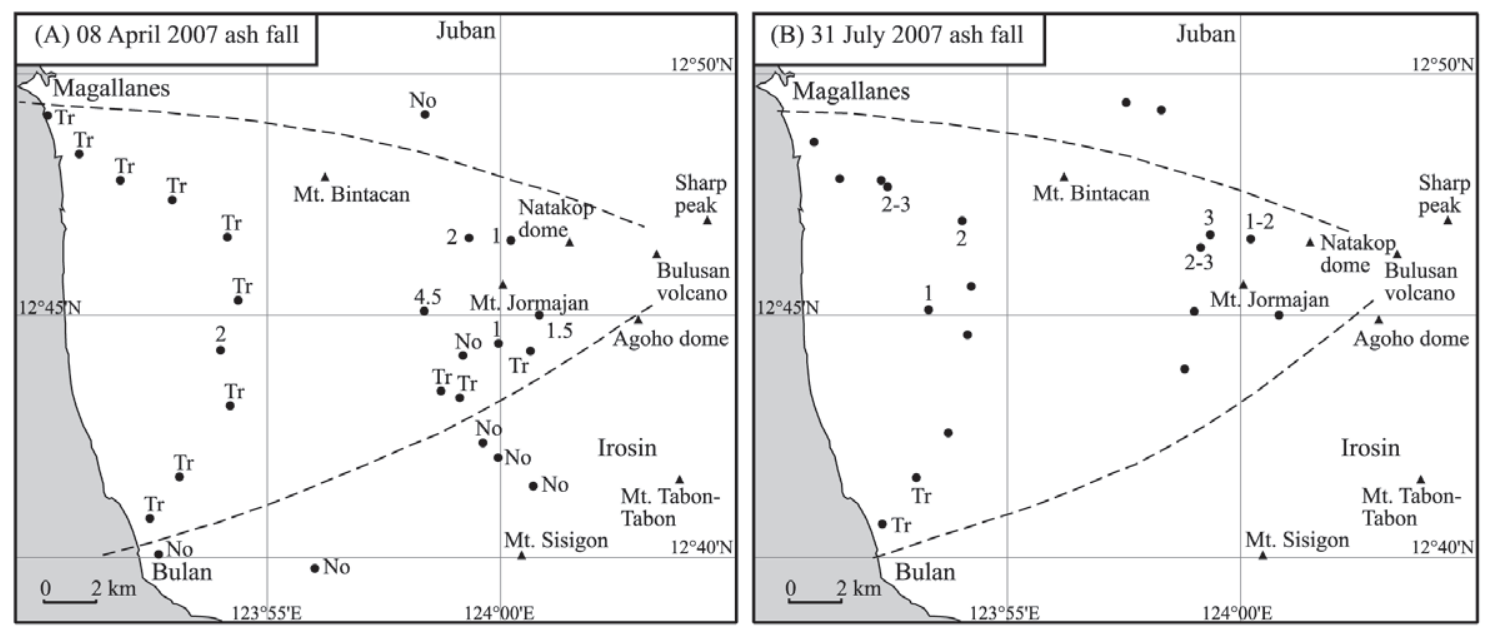

Fig. 3 Dispersal maps of ash fall from the phreatic eruptions at Bulusan volcano in 2007 (modified from PHIVOLCS Bulletins and QRT results). (A) Broken line showing the distribution of April 8, 2007 ash fall. (B) Broken line showing the distribution of July 31, 2007 ash fall.

phreatic activity resumed as an explosive event on October 10, propelling an ash column $3 \mathrm{~km}$ above the summit vent. A series of eruptive events followed on October 19, 23, 25, 30, and December 20, 2006 (Table 2).

\section{2) The 2007 eruptive events and fallout tephra}

Phreatic eruptions recurred on January 24 and 26, 2007 accompanied by explosion-type earthquakes and fallout tephra (Table 3). Volcanic activity waned until a new swarm of high-frequency volcanic earthquakes began on April 5, preceding a series of eruptive events. The first of these was the April 8 explosion, which produced an ash column $4 \mathrm{~km}$ above the summit vent, and showered the western sector of the volcano with thin ash fall. After this event, a new fissure was observed in the northern portion of the volcano summit. Another eruptive event occurred on April 9, but it was obscured. A QRT was again dispatched on April 12-17, 2007 to document the resumption of activity. Mapping and sampling of in situ April deposits was not possible because rain had washed away the associated fallout tephra. However, the extents of the deposit could be constrained in the field, and deposit thicknesses in localities were reasonably documented through remnant deposits and resident interviews (Bornas et al., 2007a, b, c). It was through interviews that local vernacular words for the particle sizes of fallout tephra resurfaced, a feature unique to communities surrounding Bulusan. Although residents called fine ash "abo" similar to most Pilipino dialects, they had special names for medium- to coarse-sandgrained ash, "baybay" and lapilli, "batiris" that were aptly used to describe the April fallout (Table 4). Figure $3 \mathrm{~A}$ shows the extent of the terrestrial fallout area, approximately $260 \mathrm{~km}^{2}$. Assuming an average thickness of $1 \mathrm{~mm}$, the total terrestrial fallout volume was conservatively estimated at $2-3 \times 10^{5} \mathrm{~m}^{3}$.

At $0937 \mathrm{~h}$ PST on July 31, 2007, Bulusan erupted for the last time that year, propelling a 5 -km-high eruption column visible in neighboring Albay Province (Tables 3 and 5). The top of the eruption column was observed as being sheared off by tropospheric winds, and remained suspended for approximately $1.5 \mathrm{~h}$ prior to complete fallout (Bornas et al., 2007d). Another QRT was dispatched for mapping of the fallout tephra, sampling, and an aerial survey onboard Philippine Air Force helicopters. Figure 3B shows the areal extent of the terrestrial fallout area, which covered roughly $220 \mathrm{~km}^{2}$. Assuming an average thickness of 
Table 2 Chronology of the Bulusan volcano eruptions in 2006 (compiled from PHIVOLCS Volcano Bulletins).

$\begin{array}{llll}\text { Date } & \text { Time (PST) } & \begin{array}{c}\text { Eruptive activity and } \\ \text { related phenomena }\end{array} & \text { Seismic data }\end{array}$

19 Mar. $0600 \quad$ Raised Alert Level from 0 to 1

21 Mar. 2258-2318 Phreatic eruption with lightning flashes and rumbling sounds; $1.5 \mathrm{~km}$ column; drifted $\mathrm{N}, \mathrm{W}$, and SW

21 Mar. 2330, 2332 Phreatic eruption; no visual and 2337 siting because summit obscured

08 Apr. 2000

Lahar reported along Cogan spillway; debris flow with small $\operatorname{logs}$

09 Apr. 1036-1058 Lahar reported along Cogon spillway;

29 Apr. 1044-1144 Phreatic eruption with faint rumbling sounds heard along western sector of Bulusan; drifted WSW and NW; fight gray ash column that rose to about $1.5 \mathrm{~km}$ above the summit; drifted WSW and NW

25 May 2117-2130 Phreatic eruption; summit obscured

31 May 1617-1632 Phreatic eruption drifted $\mathrm{W}$ and WNW; light gray ash column that rose to about $1.5 \mathrm{~km}$ above summit

07 Jun. 2017-2030 Phreatic eruption with ash column that rose to about $2.0 \mathrm{~km}$ above summit; drifted SW, $\mathrm{N}$ and W; raised Alert Level from 1 to 2

10 Jun. 1218-1243

Phreatic eruption with ash column that rose to $1.0 \mathrm{~km}$ above summit; drifted $\mathrm{NE}$ and E

73 high-frequencytype imperceptible volcanic earthquakes; swarm lasted until 21 Mar.

\section{Explosion-type earthquake}

Explosion-type earthquakes

3 explosion-type earthquakes

Explosion-type earthquake

Explosion-type earthquake

Explosion-type earthquake; another smatter E-type earthquake at 0226 of 08 Jun.

Explosion-type earthquake with rumbling sound and lightning flashes
Municipality of lrosin-Barangays Cogan, Tinampo, Gulang-gulang and Bolos (light ash fall); Municipality of Juban-Barangays Puling Sapa and Bura-Buran (light ash fall)

Channel confined; lahar deposited $3 \mathrm{~km}$ downstream at Gulang-Gulang Bridge; road to Mt. Jormajan impassable

Channel confined; lahar signal detected by Jorma-an seismic station

Municipality of Juban-Light ash fall in Barangays Sangkayon, Bura-Buran and Aniog Municipality of IrosinBarangay Cogan

Municipality of Juban-Barangays Bacolod, Sangkayon, Puling Sapa, Rangas, Mapili, Caladgao and Bura-Buran Municipality of Irosin-, Barangay Bolos

Ash deposits ranged from trace to $2 \mathrm{~mm}$ thick; affected Municipality of Juban-

Barangays Bacofod, Sangkayon, Puling

Sapa, Caladgao and Bura-Buran Municipality of lrosin-Barangays Bolos and Cogon

Municipality of Juban-Barangays Sangkayon, Aroroy (trace) and Juban Proper (1 mm thick) Municipality of lrosin-Barangays Bolos and Gulanggulang Municipality of CasiguranCasiguran Proper (0.5-2 mm), lnfagadian (light ash fall), San Juan and Ponong $(2 \mathrm{~mm})$, San Antonio $(1 \mathrm{~mm})$

Municipality of Bulusan-Barangays San Isidro, Sta. Barbara, Buang and Purog Municipality of CasiguranBarangays lnlagadian \& Escuafa 
Table 2 (continue)

\begin{tabular}{|c|c|c|c|c|}
\hline Date & Time (PST) & $\begin{array}{l}\text { Eruptive activity and } \\
\text { related phenomena }\end{array}$ & Seismic data & Dispersal / Areas affected \\
\hline 13 Jun. & $1904-1917$ & $\begin{array}{l}\text { Phreatic eruption with ash } \\
\text { column that rose to about } \\
1.5 \mathrm{~km} \text { above summit; drifted } \\
\mathrm{NW}\end{array}$ & $\begin{array}{l}\text { Explosion-type } \\
\text { earthquake with } \\
\text { rumbling sounds } \\
\text { and lightning } \\
\text { flashes }\end{array}$ & $\begin{array}{l}\text { Municipality of Juban-Barangays } \\
\text { Aroroy, Mabini and Aniog (heavy ash } \\
\text { fall at least } 7 \mathrm{~mm} \text { ), Bacolod and south } \\
\text { of Juban Poblacion (light ash fall } \\
1 \mathrm{~mm} \text { ) Municipality of Casiguran-San } \\
\text { Juan (trace) }\end{array}$ \\
\hline 18 Jun. & 1556 & $\begin{array}{l}\text { Phreatic eruption with ash } \\
\text { column that rose to ca. } 1.5 \mathrm{~km} \\
\text { above summit; drifted W }\end{array}$ & $\begin{array}{l}\text { Explosion-type } \\
\text { earthquake }\end{array}$ & $\begin{array}{l}\text { Municipality of lrosin-Barangays Bolos, } \\
\text { Sangkayon }(5 \mathrm{~mm}) \text { and Puling Sapa }\end{array}$ \\
\hline 20 Jun. & 2013 & $\begin{array}{l}\text { Phreatic eruption; summit } \\
\text { obscured; lahar occurrence }\end{array}$ & $\begin{array}{l}\text { Explosion-type } \\
\text { earthquake; lahars } \\
\text { generated with } \\
\text { lahar signals } \\
\text { recorded for } 17 \mathrm{~min} .\end{array}$ & Coincided with heavy rains \\
\hline 24 Jun. & 2300 & $\begin{array}{l}\text { Lahar occurrence Cogan } \\
\text { spillway with ave. Thickness } \\
\text { of deposits ca. } 3 \mathrm{~m}\end{array}$ & $\begin{array}{l}\text { No Lahar signals } \\
\text { recorded }\end{array}$ & $\begin{array}{l}\text { Channel confined; debris flow with } \\
\text { boulder-sized rocks at upper reach; } \\
\text { hyperconcentrated streamflow at lower } \\
\text { reach of the channel }\end{array}$ \\
\hline 28 Jun. & $0206-0210$ & $\begin{array}{l}\text { Phreatic eruption; summit } \\
\text { obscured }\end{array}$ & $\begin{array}{l}\text { Explosion-type } \\
\text { earthquake }\end{array}$ & \\
\hline 29 Jun. & & $\begin{array}{l}\text { Lowering of Alert Level from } \\
2 \text { to } 1\end{array}$ & & \\
\hline 10 Oct. & $1716-1725$ & $\begin{array}{l}\text { Phreatic eruption with ash } \\
\text { column that rose to ca. } 3 \mathrm{~km} \\
\text { above summit; drifted SW-SSE }\end{array}$ & $\begin{array}{l}\text { Explosion-type } \\
\text { earthquake } \\
\text { accompanied by } \\
\text { rumbling sound } \\
\text { heard as far as } 6 \mathrm{~km} \\
\text { from the summit }\end{array}$ & $\begin{array}{l}\text { Municipality of lrosin-Barangays San } \\
\text { Benon, Sto. Domingo and Patag (5- } \\
1.5 \mathrm{~mm} \text { thick) Municipality of Bulusan- } \\
\text { Barangays San Roque, San Rafael, San } \\
\text { Francisco, Dangkalan and Bulusan } \\
\text { Proper }\end{array}$ \\
\hline 19 Oct. & $1844-1846$ & $\begin{array}{l}\text { Phreatic eruption with no } \\
\text { description of ash column }\end{array}$ & $\begin{array}{l}\text { Explosion-type } \\
\text { earthquake }\end{array}$ & $\begin{array}{l}\text { Light ash fall experienced at Barangays } \\
\text { Tinampo and Cogan in Irosin }\end{array}$ \\
\hline 23 Oct. & 0630 & $\begin{array}{l}\text { Phreatic eruption with } 1.0 \mathrm{~km} \\
\text { ash column; drifted SW and SE }\end{array}$ & $\begin{array}{l}\text { Explosion-type } \\
\text { earthquake } \\
\text { accompanied by } \\
\text { rumbling sounds }\end{array}$ & $\begin{array}{l}\text { Municipality of Irosin-Barangays } \\
\text { Monbon and Tinampo ( } 0.5 \mathrm{~mm} \text { thick), } \\
\text { Gulang-gulang (trace) }\end{array}$ \\
\hline 25 Oct. & 0930 & $\begin{array}{l}\text { Minor lahar occurrence and } \\
\text { mud stream flow }\end{array}$ & & $\begin{array}{l}\text { Channel-confined in Barangay Cogan, } \\
\text { Gulana-aulana in lrosin }\end{array}$ \\
\hline 30 Oct. & $1156-1227$ & $\begin{array}{l}\text { Phreatic eruption with } 1.0 \mathrm{~km} \\
\text { ash column; drifted } \mathrm{N} \text { and } \mathrm{NW}\end{array}$ & $\begin{array}{l}3 \text { explosion-type } \\
\text { earthquake } \\
\text { accompanied by } \\
\text { rumbling sounds }\end{array}$ & $\begin{array}{l}\text { Municipality of Casiguran-Barangays } \\
\text { lnlagadian, San Juan, Casay and } \\
\text { Escuafa (trace to } 1.0 \mathrm{~mm} \text { ) Municipality } \\
\text { of Gubat-Barangays Bentuco, Tugawe, } \\
\text { Benguet, Rizal, Buenavista, Ariman, } \\
\text { Tabi, Bulacan, Panoaniban, Carriedo } \\
\text { and Gubat Prover }\end{array}$ \\
\hline 20 Dec. & 0109-0129 & $\begin{array}{l}\text { Phreatic eruption with } 1.0 \mathrm{~km} \\
\text { ash column; drifted } \mathrm{N} \text { and } \mathrm{NW}\end{array}$ & $\begin{array}{l}\text { Explosion-type } \\
\text { earthquake } \\
\text { accompanied by } \\
\text { rumbling sounds } \\
\text { and lightning } \\
\text { flashes }\end{array}$ & $\begin{array}{l}\text { Municipality of irosin-Barangays } \\
\text { Casini }(4 \mathrm{~mm}), \text { Tulay }(3 \mathrm{~mm}) \text {, } \\
\text { Salvacion }(2.5 \mathrm{~mm}) \text { Monbon and } \\
\text { Buenavista }(1.5 \mathrm{~mm}) \text {, Liyang }(1 \mathrm{~mm}) \text {, } \\
\text { and Poblacion }(0.5 \mathrm{~mm}) \\
\text { Municipality of Bulan-Trece and Gate } \\
\text { (trace) }\end{array}$ \\
\hline
\end{tabular}


Table 3 Chronology of the Bulusan volcano eruptions in 2007 (compiled from PHIVOLCS Bulletins).

\begin{tabular}{cl}
\hline Date Time (PST) & \multicolumn{1}{c}{$\begin{array}{c}\text { Eruptive activity and } \\
\text { related phenomena }\end{array}$} \\
\hline 24 Jan. 2206-2216 & Phreatic eruption \\
25 Jan. 2228-2224 & $\begin{array}{l}\text { Phreatic eruption with 1.0 km } \\
\text { ash column; drifted SW }\end{array}$ \\
07 Apr. 48 hr & $\begin{array}{l}\text { Seismic swarm, advisory } \\
\text { issued }\end{array}$ \\
observation & $\begin{array}{l}\text { Phreatic eruption with } \\
\text { 4.0 km ash column; drifted } \\
\text { SW; small lahars and muddy } \\
\text { streamflows along proximal } \\
\text { reach of the channels on } \\
\text { southwest flank }\end{array}$ \\
\hline
\end{tabular}

09 Apr. 0611-0631 Phreatic eruption; not observed due to thick rain clouds that covered the volcano's upper slopes Another phreatic eruption 0716-0736

$\begin{array}{ll}9-11 & 72 \mathrm{hr} \\ \text { May } & \text { observation }\end{array}$

12 May 1030-1105 Phreatic eruption with 4.0 km

12 to $0800-0800 \quad$ Seismic swarm 19 May

20 May $24 \mathrm{hr}$ observation

$13 \mathrm{Jul}$ ash column; drifted WSW and WNW

Seismic swarm

Phreatic eruption with $4.0 \mathrm{~km}$
ash column; drifted WSW and
WNW

Explosion-type earthquake accompanied by rumbling sounds

Explosion-type earthquake

Explosion-type earthquake

68 high frequencytype imperceptible volcanic earthquakes

Explosion-type earthquake

42, 65 and 97 highfrequency-type imperceptible volcanic earthquakes, respectively

Explosion-type earthquake with rumbling sound
83, 7, 51, 93, 92, 78 and 187 highfrequency type imperceptible volcanic earthquakes, respectively

Seismic swarm; raising of Alert Level from 1 to 2

Lowered Alert Level from 2 to 1
223 high-frequencytype imperceptible volcanic earthquakes

Since 20 May 2006 ash ejection, all monitored key parameters including seismic showed a decline in activity
Municipality of lrosin-Barangays Cogan, Monbon, Tinampo and Gulang-gulang Municipality of Juban-Barangays Snagkayon, Bura-buran and Bacolod Municipality of Magallanes-Barangay Siuton Municipality of Bulan-Barangays Cadandanan, Busay, Palale, San

Francisco and Sumaqonqsonq 
Table 3 (continue)

\begin{tabular}{|c|c|c|c|c|}
\hline Date & Time (PST) & $\begin{array}{l}\text { Eruptive activity and } \\
\text { related phenomena }\end{array}$ & Seismic data & Dispersal / Areas affected \\
\hline 31 Jul. & $0937-0957$ & $\begin{array}{l}\text { Phreatic eruption with } 5.0 \mathrm{~km} \\
\text { ash column; drifted WSW and } \\
\text { WNW }\end{array}$ & $\begin{array}{l}\text { No significant } \\
\text { increase } \\
\text { in seismic activity } \\
\text { prior to ash ejection; } \\
\text { explosion-type } \\
\text { earthquake with } \\
\text { rumbling sound }\end{array}$ & $\begin{array}{l}\text { Municipality of lrosin-Barangays Bolos } \\
\text { and Caladgao }(2.5 \mathrm{~mm}) \text {, Omagom } \\
(1.5 \mathrm{~mm}) \text {, Cogan, Gulang- gulang and } \\
\text { Gabao }(1 \mathrm{~mm}), \text { Municipality of Juban- } \\
\text { Barangays Puling Sapa and Sangkayon } \\
(3 \mathrm{~mm}), \text { Bura-buran }(2 \mathrm{~mm}) \text { and } \\
\text { Bacolod }(0.5 \mathrm{~mm})\end{array}$ \\
\hline 04 Oct. & $\begin{array}{l}0134 \text { and } \\
0139\end{array}$ & $\begin{array}{l}\text { Phreatic eruption not visually } \\
\text { observed; slight inflation at } \\
\text { the NE flank of the volcano } \\
\text { (03 Oct. reading) }\end{array}$ & $\begin{array}{l}\text { No significant increase } \\
\text { in seismic activity } \\
\text { since the } 31 \text { Jul. } \\
\text { eruption except during } \\
\text { the past } 24 \mathrm{hr} \text { with } \\
40 \text { high-frequency- } \\
\text { type imperceptible } \\
\text { volcanic earthquakes; } \\
\text { explosion-type } \\
\text { earthquake }\end{array}$ & $\begin{array}{l}\text { Municipality of Bulusan-Barangays } \\
\text { Upper San Jose (1 mm), Lower San } \\
\text { Jose ( } 0.5 \mathrm{~mm}) \text {, San Roque, San Rafael, } \\
\text { Sitio Tawog of Porog, Porog Proper and } \\
\text { Bulusan Proper (light ash fall to trace) }\end{array}$ \\
\hline $\begin{array}{c}15-16 \\
\text { Oct. }\end{array}$ & & Lahar occurrences & $\begin{array}{l}\text { Coincided with } \\
\text { recorded high } \\
\text { frequency signals at } \\
\text { Upper lnlagadian } \\
\text { seismograph }\end{array}$ & $\begin{array}{l}\text { SE area (Mapaso)-debris flow with } \\
\text { boulders and sand SW area (Monbon, } \\
\text { Cogon, Gulang-gulang) -debris flow } \\
\text { with small logs, boulders and sand NW } \\
\text { area (Ranga, Anog)-muddy streamflow } \\
\text { boulders; channel confined }\end{array}$ \\
\hline
\end{tabular}

$1 \mathrm{~mm}$, the total terrestrial fallout volume was estimated at $2 \times 10^{5} \mathrm{~m}^{3}$.

\section{Petrological and grain size characteris- tics of the 2006-2007 Bulusan ash falls}

\section{1) Experimental procedure}

Fallout tephra samples were collected from almost all Bulusan eruptive events in 2006 and 2007 (Table 6). The samples were analyzed for possible inputs from juvenile magma, as a method of detecting precursors of a potentially larger magmatic eruption. Mineral and lithic compositions of the ash were identified under a petrographic microscope. Thin sections were prepared by smearing ash samples on a slide then polishing to an ideal thickness. Bulk ash and lithic fragments were further analyzed for geochemical composition using a Shimadzu 1800 X-ray fluorescence (XRF) spectrometer at PHIVOLCS. Samples were fused into glass beads with proportions of $0.7000 \mathrm{~g}+/-0.0005 \mathrm{~g}$ of sample and $7.000 \mathrm{~g}+/-$ $0.0005 \mathrm{~g}$ of flux $\left(\mathrm{Li}_{2} \mathrm{~B}_{4} \mathrm{O}_{7}-\mathrm{LiBO}_{2}\right)$. Major element concentrations were determined by quantitative analysis using calibration lines from established standards (JB-3, JB-1a, JA-2, JG-3, JA-1, JG-1a). Two standards were analyzed as unknowns to test for accuracy. Grain size analysis was performed with a wet sieve, using $20 \mathrm{~g}$ of limited samples and $150 \mathrm{~g}$ of more-abundant samples, to identify ash samples suitable for XRF analysis.

\section{2) Sample descriptions}

Table 5 shows the basic petrologic descriptions of selected fallout tephra samples. The majority of the samples were composed of gray, fine- to medium-sand ash. One sample (BV070731Sangk) contained coarser grains with some lapillisized clasts. In thin section, the ash samples were composed of minerals, lithics, and brown glass fragments that were sometimes devitrified (e.g., BV-070512). Identified mineral components included plagioclase, pyroxene, amphibole, and biotite. Glass shards were neither cuspate nor platy, indicating that fresh magma may not have been involved in the phreatic events.

Analysis of major element compositions by XRF was performed on selected bulk ash samples. Samples BV070512-Juban and BV070512-Bulan were collected from different localities from the 
Table 4 Fallout tephra survey for the April 8, 2007 eruption of the Bulusan volcano (after Bornas et al., 2007a-d).

\begin{tabular}{|c|c|c|c|c|c|c|c|c|}
\hline Lattitude & Longitude & Barangay / Site & Municipality & Ash fall & Date & Time (PST) & Ash fall Description & Additional Information \\
\hline \multirow[t]{3}{*}{12.7501} & 124.0129 & Cogan & Irosin & ca. $2 \mathrm{~mm}$ & 09 Apr. & 0500 & Fine and sandy ash & $\begin{array}{l}\text { Lahar shortly after ash } \\
\text { fall; Ash fall following } \\
\text { eruption rumbling sound } \\
\text { with lightning }\end{array}$ \\
\hline & & & & Trace & 12 Apr. & & & \\
\hline & & & & None & 08 Apr. & & & \\
\hline 12.7495 & 124.0112 & $\begin{array}{l}\text { Cogan } \\
\text { Elementary } \\
\text { School }\end{array}$ & Irosin & $1.5 \mathrm{~mm}$ & & & & Ash sample (remnant) \\
\hline 12.738 & 124.0098 & $\begin{array}{l}\text { Tinampo } \\
\text { Elementary } \\
\text { School }\end{array}$ & Irosin & Trace & & & & Ash sample (disturbed) \\
\hline 12.7404 & 123.9987 & Gulang-gulang & Irosin & ca. $1 \mathrm{~mm}$ & 08 Apr. & $0700-0800$ & Fine ash & $\begin{array}{l}\text { Eruption with rumbling } \\
\text { sound; AF with lig htning } \\
\text { and followed by rainfall }\end{array}$ \\
\hline 12.7360 & 123.9864 & $\begin{array}{l}\text { Gabao High } \\
\text { School }\end{array}$ & Irosin & None & & & & $\begin{array}{l}\text { Rumbling sound ca. } 0630 \\
\text { AM. }\end{array}$ \\
\hline 12.7513 & 123.9730 & $\begin{array}{l}\text { Guruyan } \\
\text { Elementary } \\
\text { School }\end{array}$ & Irosin & 4-5 mm & 08 Apr. & 0530 & Fine and sandy ash & Ash sample \\
\hline 12.6626 & 123.9335 & $\begin{array}{l}\text { N. Roque } \\
\text { Elementary } \\
\text { School }\end{array}$ & Bulan & None & & & & \\
\hline 12.6677 & 123.8788 & Zone 8 & Bulan & None & & & & \\
\hline 12.6803 & 123.8756 & Imelda & Bulan & Trace & 08 Apr. & 0600 & Fine ash & \\
\hline 12.6940 & 123.8857 & Somagongsong & Bulan & Trace & 08 Apr. & $0700-0800$ & $\begin{array}{l}\text { Fine ash lasting until } \\
1100\end{array}$ & \\
\hline 12.7184 & 123.9036 & San Francisco & Bulan & $>$ Trace & 08 Apr. & 0600 & $\begin{array}{l}\text { Fine and sandy ash, } \\
\text { lasting before noon }\end{array}$ & Rain fall in $\mathrm{PM}$ \\
\hline 12.7385 & 123.9007 & E. Quirino & Bulan & $2 \mathrm{~mm}$ & 08 Apr. & 0600 & $\begin{array}{l}\text { Sandy ash lasting } \\
\text { until noon, smelly }\end{array}$ & $\begin{array}{l}\text { Sound like loud thunder } \\
\text { heard before ash fall; rain } \\
\text { fall next day }\end{array}$ \\
\hline 12.7558 & 123.9067 & Cadandanan & Bulan & Trace & 08 Apr. & 0700 & $\begin{array}{l}\text { Fine ash, lasting } 30 \\
\text { mins, sulfur smell }\end{array}$ & Rain fall the next day \\
\hline 12.7773 & 123.9025 & Tula-tula Sur & Magallanes & Trace & 08 Apr. & 0800 & $\begin{array}{l}\text { Fine ash lasting } 20 \\
\text { mins }\end{array}$ & $\begin{array}{l}\text { With simultaneous rain } \\
\text { fall }\end{array}$ \\
\hline 12.7894 & 123.8828 & Siuton & Magallanes & Trace & 08 Apr. & 0700 & Fine ash & Ensuinq rainfall \\
\hline 12.7963 & 123.8654 & Siuton & Magallanes & Trace & 08 Apr. & 0800 & $\begin{array}{l}\text { Fine ash, intermittent } \\
\text { for } 2 \mathrm{hrs}\end{array}$ & Ensuing drizzle \\
\hline 12.8056 & 123.8498 & Caditaan & Magallanes & Trace & 08 Apr. & 0700 & $\begin{array}{l}\text { Fine ash, intermittent } \\
\text { all day (?) }\end{array}$ & \\
\hline 12.8196 & 123.8389 & Aguada Sur & Magallanes & Trace & 08 Apr. & 0800 & Intermittent ash & Rainfall in the PM \\
\hline 12.8203 & 123.9724 & Lahong & Magallanes & None & & & & \\
\hline 12.6914 & 124.0110 & Salvacion & Irosin & None & & & & \\
\hline 12.7009 & 123.9987 & Satang & Irosin & None & & & & \\
\hline 12.7066 & 123.9933 & Gumapao & Irosin & None & & & & \\
\hline 12.7215 & 123.9848 & Tong dol & Irosin & Trace & 08 Apr. & 0700 & Fine ash, lasting $2 \mathrm{hrs}$ & Drizzle the next AM \\
\hline 12.7239 & 123.9780 & Tong dol & Irosin & $>$ Trace & 08 Apr. & 0600 & Fine ash, lasting $1 \mathrm{hr}$ & \\
\hline 12.7759 & 124.0037 & Putting Sapa & Juban & $1 \mathrm{~mm}$ & 08 Apr. & 0600 & $\begin{array}{l}\text { Fine and sandy ash, } \\
\text { lasting } 1 \mathrm{hr}\end{array}$ & $\begin{array}{l}\text { Rain fall the next AM; ash } \\
\text { sample }\end{array}$ \\
\hline 12.7767 & 123.9891 & $\begin{array}{l}\text { Sangkayon } \\
\text { Elem School }\end{array}$ & Juban & $2 \mathrm{~mm}$ & & & Fine and sandy ash & Ash sample (disturbed) \\
\hline
\end{tabular}


Table 5 Fallout tephra survey for the July 31, 2007 eruption of the Bulusan volcano (after Bornas et al., 2007a-d).

\begin{tabular}{|c|c|c|c|c|c|c|c|}
\hline Locality & Latitude & Longitude & Grainsize & Thickness & Description & Respondents / Remarks & Time / Duration \\
\hline $\begin{array}{l}\text { Puling Sapa, } \\
\text { Juban }\end{array}$ & 12.7759 & 124.0035 & $\begin{array}{l}\text { Lapilli ( } \max \\
2 \mathrm{~cm} \text { ) with } \\
\text { minor fine ash }\end{array}$ & 1 to $2 \mathrm{~mm}$ & $\begin{array}{l}\text { Grains mainly angular } \\
\text { unvesiculated andesite, } \\
\text { minor hydrothermally } \\
\text { altered lithics }\end{array}$ & & $\begin{array}{l}5 \text { min. after } \\
\text { eruption } \\
\text { onset / } 30 \mathrm{~min} .\end{array}$ \\
\hline $\begin{array}{l}\text { Sangkayon } \\
\text { Elementary } \\
\text { School, Juban }\end{array}$ & 12.7768 & 123.9893 & $\begin{array}{l}\text { Lapilli with } \\
\text { minor fine ash }\end{array}$ & $3 \mathrm{~mm}$ & $\begin{array}{l}\text { Similar to Puling Sapa, } \\
\text { few larger lapilli }\end{array}$ & & \\
\hline Bolos, Juban & 12.7510 & 123.9842 & $\begin{array}{l}\text { Coarse with } \\
\text { minor fine ash }\end{array}$ & & & & \\
\hline Cogan, Irosin & & & & & & $\begin{array}{l}\text { BRGY. CAPT.: "Batiris" could be } \\
\text { heard hitting rooftops; estimates } \\
\text { column height at } 5 \mathrm{~km}\end{array}$ & $\begin{array}{l}5 \text { mins after } \\
\text { eruption } \\
\text { onset / } 30 \mathrm{~min} .\end{array}$ \\
\hline Lahong, Juban & 12.8202 & 123.9721 & No ash fall & & & $\begin{array}{l}\text { BELEN CELINO: Audible } \\
\text { sounds described as "dalugdog", } \\
\text { "hagubuhub", "parang sinapna" }\end{array}$ & \\
\hline Lahong, Juban & 12.8228 & 123.9596 & Trace & & & $\begin{array}{l}\text { JUDITH MERCADERO: } \\
\text { Audible sounds described as } \\
\text { "hugalbung"; smell of sulfur }\end{array}$ & \\
\hline $\begin{array}{l}\text { Caditaan, } \\
\text { Magallanes }\end{array}$ & 12.8096 & 123.8495 & & & & $\begin{array}{l}\text { MON MORTEGA: coarse ash } \\
\text { ("baybay") with fine ash; smell } \\
\text { of sulfur }\end{array}$ & $1000 / 30 \mathrm{~min}$. \\
\hline $\begin{array}{l}\text { Ibalon, Siuton, } \\
\text { Magallanes }\end{array}$ & 12.7967 & 123.8587 & $\begin{array}{l}\text { Coarse with } \\
\text { minor fine ash }\end{array}$ & & $\begin{array}{l}\text { Remnant deposits on } \\
\text { leaves }\end{array}$ & Passerby & $1000 / 30 \mathrm{~min}$. \\
\hline $\begin{array}{l}\text { Siuton, } \\
\text { Magallanes }\end{array}$ & 12.7960 & 123.8730 & Coarse ash & & & & \\
\hline $\begin{array}{l}\text { Siuton, } \\
\text { Magallanes }\end{array}$ & 12.7938 & 123.8756 & & 2 to $3 \mathrm{~mm}$ & $\begin{array}{l}\text { Road thickness } \\
\text { measurement }\end{array}$ & & \\
\hline $\begin{array}{l}\text { Busay, } \\
\text { Magallanes }\end{array}$ & 12.7822 & 123.9018 & & $>$ ca. $2 \mathrm{~mm}$ & & $\begin{array}{l}\text { ALMA SIMON: "baybay" falling } \\
\text { loudly ("lagatak") on leaves, } \\
\text { painful to the skin; smell of } \\
\text { sulfur }\end{array}$ & \\
\hline $\begin{array}{l}\text { Cadandanan, } \\
\text { Magallanes }\end{array}$ & 12.7595 & 123.9051 & & & & $\begin{array}{l}\text { MARLENE OPENA: gray } \\
\text { "baybay" }\end{array}$ & 0900-1200 \\
\hline Palale, Bulan & 12.7428 & 123.9039 & & & & $\begin{array}{l}\text { MADING DELFO: Coarse ash } \\
\text { ("baybay"); rain fall ca. } 1300\end{array}$ & 1200 \\
\hline $\begin{array}{l}\text { San Francisco, } \\
\text { Bulan }\end{array}$ & 12.7095 & 123.8970 & & & & $\begin{array}{l}\text { RUFINO GORDOLA: Fine ash } \\
\text { reaching the sea; rain fall at } \\
1500\end{array}$ & $\begin{array}{l}1000 / \text { until } \\
1130\end{array}$ \\
\hline $\begin{array}{l}\text { Somagongsong, } \\
\text { Bulan }\end{array}$ & 12.6932 & 123.8851 & & Trace & & $\begin{array}{l}\text { PURISIMA DIPAYA: "papatak } \\
\text { lpatak" }\end{array}$ & \\
\hline $\begin{array}{l}\text { Detachment } \\
509, \text { Bulan }\end{array}$ & 12.6776 & 123.8736 & & Trace & & $\begin{array}{l}\text { MERCED AMILANO: fine } \\
\text { ash; "tinik-tinik" } 30 \text { min. after }\end{array}$ & 1200 \\
\hline Gabao, Irosin & 12.7310 & 123.9804 & & & & $\begin{array}{l}\text { GEMMA HICAB: fine ash; } \\
\text { kicked up by vehicles; drizzle } \\
\text { (tinik-tinik) at } 1300 \text { ) }\end{array}$ & $\begin{array}{l}1000 / \text { until } \\
1300\end{array}$ \\
\hline $\begin{array}{l}\text { Guruyan } \\
\text { Elementary } \\
\text { School Guruyan, } \\
\text { Irosin }\end{array}$ & 12.7513 & 123.8897 & $\begin{array}{l}\text { Coarse with } \\
\text { minor fine ash }\end{array}$ & ca. $1 \mathrm{~mm}$ & Disturbed sample & $\begin{array}{l}\text { LOUIE CALBAYO: fine } \\
\text { with coarse ash; smell of } \\
\text { sulfur; "tinik-tinik" at 1300; } \\
\text { audible sound described as } \\
\text { "dumagundong" }\end{array}$ & $1100 /<1 \mathrm{hr}$ \\
\hline $\begin{array}{l}\text { Basketball court } \\
\text { at Sankayon, } \\
\text { Juban }\end{array}$ & 12.7736 & 123.9856 & Lapilli & 2 to $3 \mathrm{~mm}$ & Disturbed sample & $\begin{array}{l}\text { VIRGILIO GRIEGO: earliest } \\
\text { fallout were cigarette-diameter } \\
\text { grains followed by "baybay" }\end{array}$ & $\begin{array}{l}15 \text { mins after } \\
\text { emption } \\
\text { onset / } 30 \text { mins }\end{array}$ \\
\hline
\end{tabular}


Table 6 Major element composition of the Bulusan ash from the May 25, 2006 and May 12, 2007 eruptions, and composition of the lithic fragments (LAP) from the July 31, 2007 eruption.

\begin{tabular}{lcccccccc}
\hline Sample & BV060525 & $\begin{array}{c}\text { BV070512- } \\
\text { Juban }\end{array}$ & $\begin{array}{c}\text { BV070512- } \\
\text { Bulan }\end{array}$ & $\begin{array}{c}\text { BV070731- } \\
\text { LAP1 }\end{array}$ & BV070731- & BV070731- & BV070731- & BV070731- \\
$\mathrm{SiO}_{2}$ & 61.58 & 61.17 & 61.01 & 55.08 & 63.60 & 59.17 & 56.49 & 62.46 \\
$\mathrm{TiO}_{2}$ & 0.56 & 0.56 & 0.56 & 0.65 & 0.56 & 0.51 & 0.63 & 0.57 \\
$\mathrm{Al}_{2} \mathrm{O}_{3}$ & 17.56 & 17.69 & 17.78 & 15.12 & 18.97 & 18.23 & 17.96 & 17.92 \\
$\mathrm{Fe}_{2} \mathrm{O}_{3}$ & 6.75 & 6.69 & 6.62 & 8.21 & 6.41 & 6.26 & 7.68 & 11.35 \\
$\mathrm{MnO}$ & 0.07 & 0.09 & 0.10 & 0.17 & 0.05 & 0.12 & 0.16 & 0.01 \\
$\mathrm{MgO}$ & 1.83 & 2.03 & 2.11 & 4.49 & 1.94 & 3.08 & 4.13 & 0.81 \\
$\mathrm{CaO}$ & 6.48 & 6.66 & 6.79 & 11.88 & 5.05 & 7.47 & 8.21 & 4.22 \\
$\mathrm{Na}_{2} \mathrm{O}$ & 2.53 & 3.07 & 3.11 & 2.77 & 2.35 & 3.30 & 2.97 & 1.57 \\
$\mathrm{~K}_{2} \mathrm{O}$ & 1.59 & 1.81 & 1.72 & 1.44 & 0.91 & 1.69 & 1.54 & 0.95 \\
$\mathrm{P}_{2} \mathrm{O}_{5}$ & 1.05 & 0.21 & 0.20 & 0.19 & 0.17 & 0.16 & 0.23 & 0.14 \\
\hline $\mathrm{Total}^{2}$ & 91.08 & 91.7 & 92.48 & 94.66 & 93.65 & 97.69 & 97.32 & 95.98 \\
\hline
\end{tabular}

same eruption event. Lithic fragments were selected from different lithic groups based on hand specimen characteristics. Bulk ash analysis is typically not ideal because: (1) the components of ash originate from different sources (e.g., deposits of different eruptions); and (2) significant aerodynamic fractionation occurs during ash transport and deposition. Tests of selected samples, such as that of the July 31, 2007 eruption (Fig. 4), demonstrated that XRF analysis of different component sizes from a single sample yielded wide variation in composition. This shows that the analysis of bulk ash is not valid if the sample contains a high grain-size fractionation. However, fallout tephra samples that are characterized by a dominant particle size range can yield good major element compositions. For example, ash samples from the May 12, 2007 eruption yielded acceptable results from bulk ash analysis (Fig. 5). Specifically, acceptable samples include those collected $9 \mathrm{~km}$ west (BV070512-Juban) and $17 \mathrm{~km}$ southwest (BV070512-Bulan) of the crater. Both samples were composed of mostly $3 \phi$ to finer grains, specifically 80 wt.\% and 85.5 wt.\%, respectively. These samples demonstrated that bulk ash analysis could be applicable if fallout tephra is dominantly fine- to medium-grained,

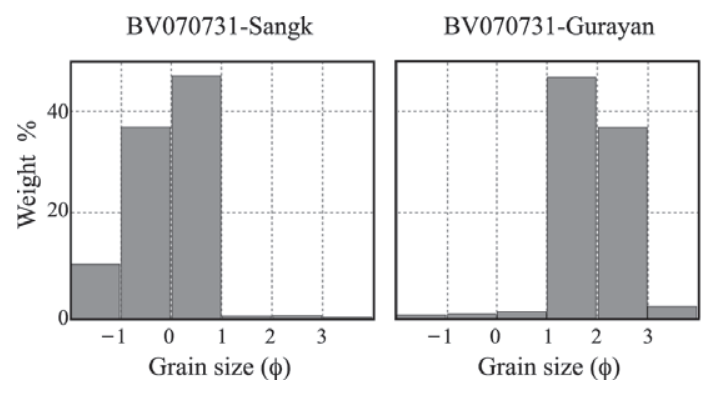

Fig. 4 Grain size distribution for ash samples from the July 31, 2007 eruption taken from Sangkayon and Gurayan, which are located 9 and $10 \mathrm{~km}$ west of the crater, respectively. High variation in grain size was observed between the two sample sites, despite the short distance between them and their mutual location west of the crater. Chemical analysis of bulk ash was not possible.

shows little grain size fractionation irrespective of distance from the vent, and is assumed to have fragmented from a homogenous source. Major element composition of the May 12 and 25, 2006 ash samples, as well as selected lapilli-sized lithic fragments from the fallout tephra of the July 31, 2007 eruptive event, are detailed in Table 6. Ash samples were andesitic in composition with consistent $\mathrm{SiO}_{2}$ of 61 wt.\%, whereas lithic compositions varied across the basaltic andesitic 


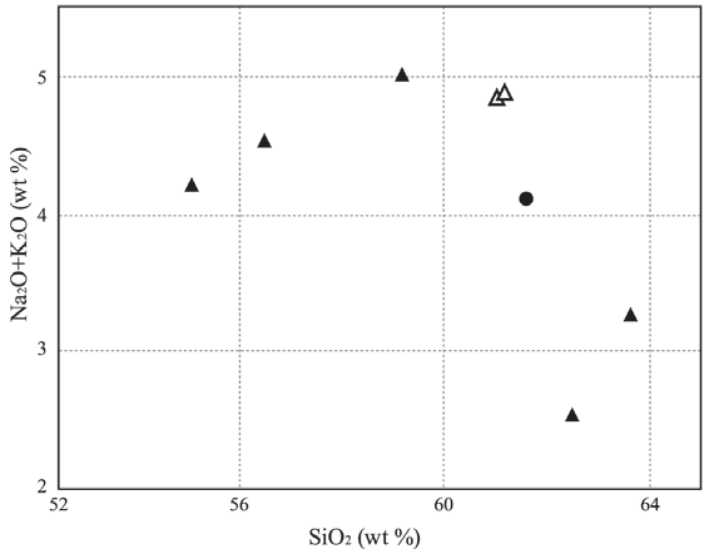

Fig. 5 Total alkali $\left(\mathrm{Na}_{2} \mathrm{O}+\mathrm{K}_{2} \mathrm{O}\right)$ versus silica $\left(\mathrm{SiO}_{2}\right)$ for bulk ash and lapilli of selected samples. Closed circle, open and closed triangles indicate samples BV060525, BV070512 (-Juban, -Bulan), BV070731 (-LAP1, -LAP2, -LAP3, -LAP4 and -LAP5), respectively. Samples collected from both sites for the May 12, 2007 ash showed a similar composition, within the andesite range. The May 25, 2006 ash plotted in the same area. The individual lapilli of BV070731-Sangk (July 31, 2007) showed greater compositional variation, ranging from basaltic andesite to dacite.

and dacite range. Both the chemistry and mineral components are consistent with those of the postcaldera volcanism, which includes Bulusan (Delfin et al., 1988, 1993; McDermott et al., 2005) .

Based on the results of these analyses, samples collected from the 2006-2007 Bulusan eruptions do not appear to be similar to ash erupted from juvenile magma. Although blocky to angular glass grains typical of andesitic ash occur in the samples, very few appeared clear and without alteration. A brown glass shard identified in the May 25, 2006 sample appeared unaltered under the petrographic microscope, but fine veins of alteration clays may be missed with this method. The wide compositional range of the analyzed lapilli from the July 31, 2007 event (Sample BV070731-Sangk) denotes multiple deposit sources (Fig. 5). Some degree of alteration can be further interpreted from the lower $\mathrm{K}_{2} \mathrm{O}$ content of the lithic samples with higher $\mathrm{SiO}_{2}$ content (Table 6). Based on texture and chemistry, it could be reasonably deduced that the lapilli-sized lithics are non-juvenile in origin. Overall, the studied samples appear to have been produced by fragmentation of pre-existing vent rock in a phreatic eruption.

\section{Concluding remarks}

The 2006 and 2007 phreatic eruptions primarily generated ash fall tephra with no significant emplacement of pyroclastic flows. All fallout tephra deposits covered the western portion of Sorsogon Peninsula. Based on dispersal maps, the volume of each tephra was approximately $10^{5} \mathrm{~m}^{3}$. Explosion-type earthquakes accompanied some eruptions. Petrographic and X-ray fluorescence analysis in the laboratory did not detect juvenile magma from any of the tephra samples.

\section{Acknowledgements}

This work is a compilation of all of the field investigations and mapping of the PHIVOLCS Quick Response Teams (QRT). The staff of the Volcano Monitoring and Eruption Prediction Division (VMEPD) consolidated the PHIVOLCS Volcano Bulletins. We are very grateful to anonymous referees for the helpful comments that improved the manuscript.

\section{Notes}

1) http://volcano.phivolcs.dost.gov.ph/update VMEPD/Volcano/VolcanoList/bulusan.htm [Cited 2011/1/25/].

\section{References}

Arpa, M.C. B., Maximo, R.P.R. and Javier, R.V. (2006): Mapping of Deposits from March to June 2006 Eruptions of Bulusan Volcano. Philippine Institute of Volcanology and Seismology, Quezon City, Unpublished Report of Investigation, 6p.

Bornas, M.A.V., Cahulogan, M.T., Tubianosa, B.S., Mirabueno, M.H.T. and Salili, N. (2007a): Report of Ocular Survey of Lahar and Muddy Streamflow Channels of Bulusan Volcano, Sorsogon Province, 15 and 17 October 2007. Philippine Institute of Volcanology and Seismology, Quezon City, Unpublished Report of Investigation, 8p.

Bornas, M.A.V., Cahulogan, M.T., Tubianosa, B.S., Laguerta, E.P., Ariola, E.M. and Solidum, R.U. (2007b): Report on Fallout Tephra Mapping and Aerial Survey of Bulusan Volcano, Sorsogon Province, 31 July-2 August 2007. Philippine Institute of Volcanology and Seismology, Quezon City, Unpublished Report of Investigation, 3p.

Bornas, M.A.V., Delos Reyes, P.J., Maximo, R.P.R. and 
Tubianosa, B.S. (2007c): Report on Ash Fall Mapping and Reconnaissance Investigation of Bulusan Volcano, Sorsogon Province, 12-17 April 2007. Philippine Institute of Volcanology and Seismology, Quezon City, Unpublished Report of Investigation, 3p.

Bornas, M.A.V., Delos Reyes, P.J., Maximo, R.P.R. and Tubianosa, B.S. (2007d): Quick Response Team Report on Mapping and Reconnaissance Investigation at Bulusan Volcano, Sorsogon Province, April 2007. Philippine Institute of Volcanology and Seismology, Quezon City, Unpublished Accomplishment Report, 2p.

Delfin, F.G., Fragata, J.J., Layugan, D.B., Panem, C.C. and Villasenor, L.B. (1988): Evaluation Summary of the Mt. Bulusan Geothermal Exploration. Unpublished Memorandum, PNOC-Energy Development Corporation, 68p.

Delfin, F.G., Panem, C.C. and Defaut, M.J. (1993): Eruptive history and petrochemistry of the Bulusan volcanic complex: Implication for the hydrothermal system and volcanic hazards of Mt. Bulusan, Philippines. Geothermics, 22, 417-434.
Kinoshita, K. and Laguerta, E. (2014): Image recordings of eruption clouds at Bulusan and Mayon volcanoes, Philippines. Journal of Geography (Chigaku Zasshi), 123, 776-788.

McDermott, F., Delfin, F. G., Defant, M.J., Turner, S. and Maury, R. (2005): The petrogenesis of volcanics from Mt. Bulusan and Mt. Mayon in the Bicol arc, the Philippines. Contribution to Mineralogy Petrology, 150, 652-670.

Okuno, M., Laguerta, E.P., Delos Reyes, P.J., Bornas, M.A.V., Mirabueno, M.H.T., Arpa, M.C.B., Bariso, E., Solidum, R.U., Taguchi, S., Torii, M. and Kobayashi, T. (2011): Eruptions of Bulusan Volcano since November 2010. Journal of the Geological Society of Japan, 117, XIV.

PHIVOLCS (2002): Volcanoes of the Philippines. Department of Science and Technology (DOST), Quezon City, 41p.

Saderra Maso, M. (1911): Volcanic eruption in the Philippines in relation to earthquake, subterranean noises, rainfall and atmospheric pressure. Bulletin of the Weather Bureau, 238-249. 


\section{フィリピン・ルソン島南部，ブルサン火山 2006-2007 年噴火による降下火山灰}

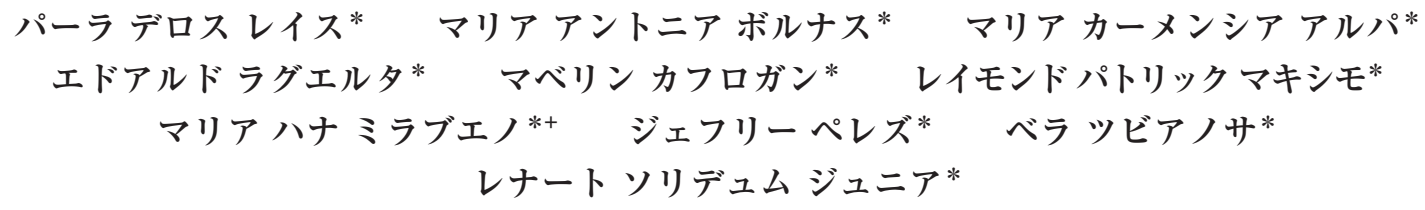

ルソン島南部のブルサン火山では, 2006 年に 19 回, 2007 年に 7 回の水蒸気噴火が発生した。 それらの噴火によるテフラは, 山頂火口の上空で 西または南西方向に吹く卓越風に運ばれ, ソルソ ゴン半島の西部地域を覆った。いくつかのイベン トでは, 爆発地震が記録された。降下テフラの分 布調査と試料採取ができた場合に，それらの噴出
量の推計と構成物質の検討を行った。それぞれの 降下テフラの体積は, 得られた分布図から, およ そ $10^{5} \mathrm{~m}^{3}$ の規模と推定された。火山灰の岩石記 載的観察や蛍光 $\mathrm{X}$ 線分析では本質物質は検出さ れず，すべて水蒸気噴火によるものと結論づけら れた。

キーワード：ブルサン火山，水蒸気噴火，降下火山灰，本質物質，フィリピン 